\title{
AZ EMBERRŐL ALKOTOTT FOGALMAK VÁLTOZÁSA A KÉSŐ FELVILÁGOSODÁSTÓL A KORA ROMANTIKÁIG
}

A Magyar Tudományos Akadémia könyvkiadási támogatásával megjelent tanulmánykötet azoknak a változásoknak a bemutatását tüzte ki céljául, amelyek a biológia, illetve a filozófiai antropológia emberről és emberiségről alkotott felfogásában végbementek a 18-19. század fordulóján.

A (főként német) biológiai antropológia diszciplináris, illetve kulturális momentumaira, továbbá ezek magyarországi recepciótörténetére összpontosító könyv négy fejezetből áll. Az első rész azt vizsgálja, hogy a 18. századi földrajzi felfedezések miként hatottak a rasszokkal, illetve az emberiség egységével kapcsolatos filozófiai vitákra. Kontler László tanulmánya azt követi nyomon, hogy a természettudományok korabeli eredményeinek hatására hogyan alakult át az emberiség fogalma a 17. század közepétől a 19. század végéig terjedő időszakban, hangsúlyozva azt a karakterisztikumot, hogy az állatok és az emberiség közötti határmegvonás erősen kontextusfüggő volt, s e tény a morálfilozófiai elméletekre nézve is messzemenő következményekkel járt. Míg például Edward Stillingfleet lehetségesnek tartotta az emberi státusz jól körülhatárolt definícióját, addig John Locke rugalmasabb megközelítést követett az emberiség definíciója kapcsán, s az erkölcsi normák kulturális meghatározottságú sokféleségét hangsúlyozta. A szerző kiemeli, hogy Friedrich Blumenbachnak és Georges-Louis Leclerc de Buffonnak az emberiség egységét hangsúlyozó elméletei hatással voltak a rabszolgasággal, illetve annak eltörlésével kapcsolatos vitákra is. Staffan Müller-Wille a rasszok sajátosságait a kontinensek földrajzi felosztásával összefüggő jelenségnek tekintő Carl von Linné rasszdefinícióira, illetve azok közvetlen előzményeire összpontosít. Wolfdietrich Schmied-Kowarzik tanulmánya Immanuel Kant és Georg Forster rasszvitájával foglalkozik, s fejlődéselméleteik eltéréseit elemezve szembeállítja tapasztalat- és teleológiafogalmaikat, illetve az emberiség eredetéröl alkotott felfogásaikat.

A könyv második fejezete a német biológiai antropológia kezdeteivel foglalkozik. Uwe Hoßfeld és Jörg Pittelkow tanulmánya rávilágít a Charles Darwin előtti antropológiai elméletek tudománytörténeti jelentőségére. Ezek három fó kérdéskörre összpontosítottak: az ember és az állatfajok viszonyára, az anatómiaimorfológiai variációkra, valamint a rasszok földrajzi különbségeire. Különös figyelmet szenteltek a szerzők Immanuel Kantnak, Blumenbachnak, Buffonnak és Johann Gottfried Herdernek, akinek Eszmék az emberiség történetének filozófiájáról címü müve a rasszokra vonatkozó antropológiai elméletek kezdetét is jelzi. 
Thomas Junker Friedrich Blumenbach mérési módszereinek a biológiai antropológia kibontakozására gyakorolt hatását értékeli. Az új diszciplináris metodikák az emberiség sajátos vonásainak azonosítását voltak hivatottak elősegíteni. Békés Vera írása a földrajzi felfedezések következményeire reflektál a test és lélek kapcsolatáról szóló viták kapcsán, különös figyelmet szentelve Georg Christoph Lichtenberg úgynevezett patognómiájának, amely Johann Kaspar Lavater fiziognómiájának egyfajta ellentendenciáját képezte.

A harmadik fejezet a német idealizmus emberképének kialakulását állítja középpontba. Hárs Endre az ember és az állat közötti megkülönböztető jegyekkel kapcsolatos vitákat taglalja, pontosabban Pietro Moscati anatómiai tanulmányait és Herdernek az értelemre mint az emberiség sajátos vonására összpontosító feltevéseit elemzi. Gurka Dezső az emberkép változásának egyik pszichológiatörténeti aspektusát vizsgálja az álom és a tudattalan fogalma kapcsán. A tanulmány Kant, Gotthilf Heinrich Shubert, s elsődlegesen Carl Gustav Carus kapcsolódó múveit kontextualizálja, bemutatva, hogy Carus Shelling természetfilozófiája nyomán dolgozta ki a tudattalan (Unbewußt) fogalmát, újfajta lehetőséget biztosítva ezzel a pszichológiai tényezőknek a betegségek diagnosztikájában és kezelésében. Klaus Vieweg tanulmánya Georg Wilhelm Friedrich Hegel emberképét vizsgálja, s arra fókuszál, hogy az esztétikai nevelés (Bildung) a szabadságra nevelés szerepét tölti be annak a dialektikus történelmi folyamatnak a keretein belül, amely a következő három fázisban valósul meg: szimbolikus művészet (keleti világ), klasszikus müvészet (antikvitás), illetve romantikus fázis (újkor).

Az utolsó fejezet a késő felvilágosodás és a kora romantika emberképének magyar recepciójával foglalkozik. Sz. Kristóf Ildikó az etnográfia 1848 előtti történetét mutatja be a korabeli német múvek és magyar interpretációik - így például Friedrich Justin Bertuch Bilderbuchjának és Georg Christian Raff könyvének magyar fordításai, illetve Dobosy Mihály átültetései - alapján. Magyarország és a német területek kulturális kapcsolata meglehetősen erős volt a 18-19. század fordulóján, hiszen Göttingenben és Jénánban sok olyan magyarországi protestáns diák tanult, akiknek fordításai is német hatásokat közvetítettek. Balogh Piroska tanulmánya Schedius Lajos esztétikai munkásságának antropológiai aspektusait tárja fel a szépség dinamikáját megalapozó filokália elmélet kapcsán. Bodnár-Király Tibor bemutatja, hogy Csernátoni Vajda Sámuel Karl Friedrich Flögel könyvéröl készült fordítása a mü új értelmezését eredményezte, s egy olyan erkölcsi megközelítésben gyökerezett, amely a haladást racionálisnak tekintette. Krász Lilla tanulmánya azt tárja fel, hogy az orvosi ismeretek szélesebb körü elterjedését és a magyar egészségügyi rendszer modernizálását miként alapozták meg és támogatták a jogszabályok, míg Kurucz György az agrártudományok fejlődésére fókuszál, bemutatva a II. József halála utáni évek magyar nemesi reformista attitüdjeit, mindenekelőtt gróf Festetics György, az első magyarországi mezőgazdasági föiskola, a Georgikon alapítója esetében. 
A kötet a 18-19. századi emberkép változásainak részletes bemutatása, illetve a magyar vonatkozások feltárása révén a témával foglalkozó antropológusok és filozófiatörténészek számára egyaránt gazdag információs bázist nyújt. A kor történelmi és elméleti dinamikájának mélyebb ismerete segítséget adhat a kor erkölcsi vitáinak megértéséhez, illetve a különféle diszciplínák kialakulási folyamatainak áttekintéséhez is. Az olyan fogalmak kontextualizálása, mint a tudattalan, a patognómia vagy a filokália, rávilágít arra, hogy az emberiség fogalmát olyan perspektívákból kell megközelíteni, amelyek képesek megmutatni, hogy ez a kategória meglehetősen képlékeny és kontextusfüggő, s nehezen ragadható meg minden részletében.

Egy, a szerzők eredményeit összegző tanulmány jelentősen növelte volna a bemutatott tendenciák áttekinthetőségét, ám a kötet írásai önmagukban is elegendő információt nyújtanak ahhoz, hogy az olvasó tisztában legyen egy olyan témának az összetettségével, amely napjainkban is alapvető fontosságú, lévén hogy az egyes emberképek abszolutizálása mindenkor társadalmi konfliktusokhoz és szélsőségekhez vezethet.

(Dezsö Gurka editor: Changes in the Image of Man from the Enlightenment to the Age of Romanticism. Philosophical and Scientific Receptions of (Physical) Anthropology in the 18-19 th Century. Budapest: Gondolat Publishers, 2019, 280 o.)

Lara Scaglia

PhD, filozófiatörténész, Narodowe Centrum Nauk, Varsó

(Fordította Gurka Éva Mária) 